\title{
Cultural Use of Homegarden Plants in an Indigenous Community in North West Ethiopia
}

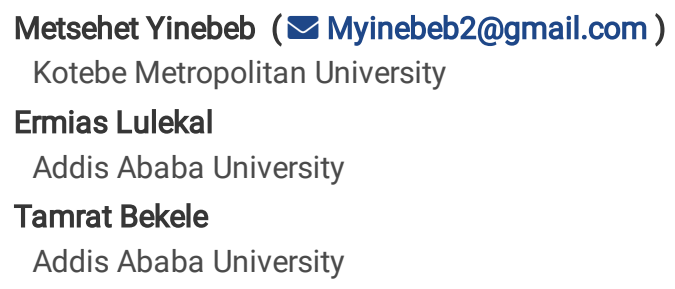




\section{Abstract}

Background; The floristic composition of homegardens in Northwest Ethiopia in general, and the Gozamin district in particular, has received little research attention. The purpose of this research is to better understand the floristic composition and cultural significance of homegardens.

Methods; Stratified random sampling procedure was used based on agroecological variation in selected kebeles. The homegarden data were collected by dividing the homegarden into four quadrats, the first quadrat stretched from the farmer's home to $10 \mathrm{~m}$, the second quadrat from $10 \mathrm{~m}$ to $20 \mathrm{~m}$, the third quadrat from $20 \mathrm{~m}$ to $30 \mathrm{~m}$ and the fourth quadrat from $30 \mathrm{~m}$ to $40 \mathrm{~m}$ horizontally using farmer's house as reference depending on the size of the garden. A semi-structured interview was carried out to document the informant's knowledge on plant species.

Results; A total of 238 culturally important plant species from 81 families were identified. Of these $39 \%$ were herbs, $29 \%$ shrubs, $6 \%$ were climbers. Perennials made up the largest part of cultivated species (83\%), whereas annuals made up the rest (17\%). The Poaceae family had the foremost species, with 22, taken after by the Fabaceae, which had 21, and the Asteraceae which had 15. From these recorded plants, $140(58.6 \%$ ) were species utilized for environmental uses, $84(35 \%)$ food crops, $83(34.7 \%)$ medicinal plant species, $39(16.3 \%)$ fodder species, $57(23.8 \%)$ material use plants, $60(25 \%)$ fuel wood species, $50(21 \%)$ social use plants and $1(0.4 \%)$ poisonous. The direct matrix ranking revealed that Cordia Africana was found a versatile culturally important plant in the area which was also extremely threatened, followed by Ficus sur. Cordia africana highest use-value was for Building and the list value was for medicinal. The Sorensen similarity index for 64 percent of the locations investigated was less than 0.5 .

Conclusion; The result showed that homegardens are multi-functional, long-term production systems. Food security and biodiversity conservation are continuously supported by tribal populations cultural knowledge connected with their homegardens. The less similarity/high species diversity in the area between kebeles indicated that there was high species diversity this was due to different range of agroecological conditions among kebeles.

\section{Background}

Gardening' is defined as the activity of working in a garden, growing and taking care of plants [1]. It can also be defined as planting multipurpose trees along with crops and livestock around the homestead [2], or preparing vegetable planting and arrangement of quality vegetable seeds to extend the year-round supply of nutrient-rich nourishment inside the family [3]. Homegardens are also critical territories for therapeutic plants all over the world [4].

Around the world, homegardens are a community's most versatile and available arrive resources and critical components in diminishing vulnerability and guaranteeing nourishment security [5]. Year-round food production, decreased risks of production failure owing to high species diversity, increased resource productivity over time, expansion of the amount and quality of labor employed in the farm, output flexibility, and alternative production are features of homegardens[6]. Concurring to Das and Das [7], homegarden frameworks give an extra nourishment supply and cash pay for the individuals. Tropical homegardens are also generally regarded as sustainable production systems [8, 9]. The choice of plant species, their arrangement and management vary between and within tropical homegardens in the same community [10].

Homegarden programs are these days more broadly executed in Africa[3,11]. The expansive concentration of the valuable plants found in Ethiopia are found in homegardens [12]. Agreeing to Eyasu et al.[13] in Northern Ethiopia gardening complements the natural forest in terms of biodiversity conservation and aids in the prevention of the extinction of woody species in the natural environment.

Farmers' seed and crop management decisions, as well as adjacent modes of living, are shaped by cultural traditions[14]. At the same time, homegardens are important social and cultural sites where agricultural expertise is passed along [15]. They also meet social necessities and give environmental administrations and serve additionally as a source of income[16].

Homegarden production, according to Kumar and Nair [17] is mostly supplementary to staple food production and primarily focuses on vegetables, fruits, and condiments. It tends to have a few trees that can be utilized for long-term generation and deal for benefit [18] Nonetheless, the wide range of products cultivated in homegardens from trees, shrubs, and herbaceous plants provide variety to rural households' diets and also serve as an important sources of cash income through the sale of surplus produce and cash crops[19]. In agreement to Landon-Lane [20] homegardens include trees, shrubs, and herbaceous plants that grow in or near a homestead or home compound, are planted and managed by family members, and the goods and services are largely for household consumption and ornamental value.

Ecological, socioeconomic, and cultural factors such as distance from urban markets, household size and composition, environmental degradation, and family tradition may influence the species composition, structure, and function of homegardens [21]. Better market access, as well as greater public promotion of homegardens, encourage their adoption, but only in more water-abundant ecologies[11]. According to 
Galluzzi et al.[15], homegardens, whether in rural or urban settings, are multifunctional, allowing them to provide a variety of advantages to ecosystems and people. Homegardens are fundamentally distinct from large-scale agricultural systems

According to Zemede and Ayele [22], the size of homegardens in Ethiopia range from 0.004 to 0.05 ha and in North Western Ethiopia from 0.004 to $0.05 \mathrm{ha}$ [23].

There was less research attention carried out on the homegarden of the present study area. The current study was undertaken aimed at documenting the composition and cultural use of plant species in homegardens of this Gozamin district, Northwest Ethiopia.

\section{Materials And Methods}

\section{Study area}

The study was carried out in Gozamin district, East Gojjam, Northwest Ethiopia. It is one of the 20 woredas of East Gojjam zone, Amhara National Regional State [24]). The relative location of the Gozamin district is $300 \mathrm{~km}$ North West of Addis Ababa, the capital city of Ethiopia, and $260 \mathrm{~km}$ southeast of Bahir Dar city, the main administrative capital of Amhara Region. Gozamin district is bounded by Aneded and Debay Tilatgen districts to the East, Machakle and Debre Elias district in west, Senan district in the North, Baso Liben district and Oromia National Regional State in the South (figure1)[24].

The agroecological zones of the district comprises of Wurch (1\%), Dega (temperate highland) $(9 \%)$, Woina Dega (sub-tropical) $(79 \%)$ and Kolla (tropical) (11\%) within altitudinal range of 800-3748 meters above sea level [24].The district covers a total area of 121,781 ha of which 50,084 ha is agricultural land followed by grazing lands 18,966 ha, forest 22,225 ha and others 30,506 ha[24].

The total population of Gozamin district was 170,690 of which 85,220 were males and 85,470 were female's [25]. Regarding to human health,there are 6 health centers, 27 health posts, 3 private clinics, and1 private pharmacy (drug stores) in the district [26].

\section{Sampling method}

The study was conducted in 12 kebeles (lowest administrative units in Ethiopia) selected in a stratified random sampling procedure based on agroecological variation. The selected kebeles were Aba Libanos, Addisenagulit, Chimit, Denba, Desa Enese, Enerata,Graram,Kebi,Wenka, Yeboargina,Yebokla,Yetegan.

The number of households from each kebeles were calculated following Cochran [27], with 95\% confidence level with a margin of error equal to (0.05).

$$
n=\frac{n_{o}}{1+\frac{\left(n_{\mathrm{o}}-1\right)}{\mathrm{N}}}
$$

$\mathrm{n}=$ number of households sampled from all kebeles

where $\mathrm{n}_{\mathrm{o}}$ is the sample size and it is expressed as $\mathbf{n}_{\circ}=\frac{z^{2} p q}{e^{2}}$

$z$ is the selected critical value of desired confidence level; $p$ is the estimated proportion of an

attribute that is present in the population, $q=1-p$ and $e$ is the desired level of precision

$\mathrm{N}=$ number of households that have homegarden in 12 kebeles

The maximum variability, which is equal to $50 \%(p=0.5)$ and taking $95 \%$ confidence level with $\pm 5 \%$ precision, the calculation for required sample size was as follows-

$\mathrm{p}=0.5$ and hence $\mathrm{q}=1-0.5=0.5 ; \mathrm{e}=0.05 ; \mathrm{z}=1.96, \mathrm{~N}=5056$

$$
\begin{aligned}
& \left.\mathrm{n}_{\mathrm{o}}=\frac{(1.96)^{2}(0.5) x(0.5}{(0.05)^{2}}\right)=384 \\
& n=\frac{384}{1+\frac{(384-1)}{5056}}=357
\end{aligned}
$$


Based on information on the Gozamin district kebeles agricultural office [28], the total number of households that have homegarden were taken, and a total of 5056 households with homegarden were recorded. Thus, from 11 kebeles 30 homegarden owners per kebele were selected and from the one kebele 27 homegarden owners were selected. Accordingly, from the 12 kebeles a total of 357 householder respondents were contacted.

According to Dissanayake and Hettiarachchi [29] for woody species in the homegarden $10 \mathrm{~m} \times 10 \mathrm{~m}\left(100 \mathrm{~m}^{2}\right)$ plot was laid. For herbaceous species 5 small plots, 4 at each corner and 1 within the middle were laid within the expansive quadrats and all plant species in the quadrats were recorded.

According to Millate-E-Mustafa et al.[30] and Zebene Asfaw et al. [23] in the homegarden data were collected by dividing the homegarden into four quadrats, in that the first quadrat started from the farmer's home to $10 \mathrm{~m}$, the second quadrat from $10 \mathrm{~m}$ to $20 \mathrm{~m}$, the third quadrat from $20 \mathrm{~m}$ to $30 \mathrm{~m}$ and the fourth quadrat from $30 \mathrm{~m}$ to $40 \mathrm{~m}$ depending on the size of the garden. The size of the homegarden in the study area reached from 0.015 ha to 0.5 ha. Accordingly, a total of 881 plots were laid across the selected homegarden.

Counting of each useful plant species (presence or absence) was conducted at each homegarden.

A semi-structured interview was carried out to document the informant's knowledge on the use of plants in the garden and information obtained was recorded and analyzed [31].

\section{Data analysis}

\section{Descriptive statistics}

Homegarden data was analyzed and summarized using different descriptive statistical methods (percentages, graphs, charts, tables.) by using Excel 2016.

\section{Similarity Indices}

The Sørensen similarity coefficient was utilized to compare the similarity with in the species composition across homegardens since it gives more weight to the species that are common within the kebeles instead of those that are present in either kebele. The Sørensen similarity index (Ss) was calculated as follows:

Ss $=2 a / 2 a+b+c$

where $\mathbf{a}$ is the number of species common to both samples, $\mathbf{b}$ is the number of species in sample1, and $\mathbf{c}$ is the number of species in sample 2 [32].

\section{Direct matrix ranking}

The direct matrix ranking approach was used to rank multifunctional plant species in order to identify culturally multipurpose important plants in the study area, beside identifying those multipurpose plants which were under higher human use pressure in the study area, as well as the threats they face. Several aspects of plants were considered, including their usage as food, fodder, environmental purposes, medicine, materials, fuel, and social uses. Out of the entire cultural relevance of plants, fifteen multifunctional tree species were chosen based on information obtained from informants, and seven use diversities of these plants were listed for 24 key informants to assign use values to each species[31]. The usage values(5=best,4=very good, $3=$ good, $2=1$ ess used, $1=$ least used and $0=$ not used) were allocated to each selected key informants. Then, the use values for each species were summarized and ranked.

\section{Use values (UV)}

Use value was used to calculate a quantitative estimate of any individual's relative cultural importance.

$\mathrm{UV} s=\sum$ Uis $/ \mathrm{ns}$

Where: UVs= Use value of species s

- U is: number of uses of species S according to informant (i)

-ns-total number of informants interviewed/consulted about use of species S[31]

\section{Results}


The size of homegardens used for plantation in the study area ranged from 0.015 to 0.5 ha. From the overall 357 homegardens, a total of 238 culturally important plant species belonging to 81 families were identified. Wenka kebele had the highest homegarden species (130 species belonging to 58 families), while Graram kebele had the least, with 59 species and 30 families (table1).

Table 1. Number of plant species in sampled kebeles

\begin{tabular}{lll} 
Study sites (Kebeles) & Number of botanical family & Number of species(richness) \\
\hline Aba Libanos & 47 & 112 \\
\hline Addisenagulit & 43 & 94 \\
\hline Chimit & 33 & 61 \\
\hline Denba & 43 & 89 \\
\hline Desa Enese & 40 & 75 \\
\hline Enerata & 41 & 93 \\
\hline Graram & 30 & 59 \\
\hline Kebi & 30 & 63 \\
\hline Wenka & 58 & 130 \\
\hline Yeboargina & 40 & 76 \\
\hline Yebokla & 35 & 67 \\
\hline Yetegan & 42 & 89 \\
\hline Total & 81 & 238
\end{tabular}

The collected 238 culturally important plant species were classified into 8 use categories based on Cook [33]. From the total plant species recorded 140(59\%) were reported to be utilized for environmental uses,84(35\%) food crops, $83(35 \%)$ medicinal plant species, 39(16.4\%) fodder species, 57(24\%) material use plant, 60(25\%) fuel wood, 49(20.6\%) social use plants and 1(0.42\%) Poisonous plant (figure 2).

Among the 238 plant species, 15(6.3\%) were climbers, 93(39\%) were herbs, 69(29\%) shrubs, other $61(25.6 \%)$ were trees (figure 3). Poaceae had the highest number of species recorded with 22(9.2\%) species followed by Fabaceae with 21(8.8\%) plant species and Asteraceae with 15(6.3\%) species. Most homegarden species were perennials (83\%) while annuals were the least (17\%).

\section{Cultural use classification of collected plant species}

\section{Food crops}

A total of $84(35 \%)$ food crops used as sources of fruit, vegetables, cereals, beverages, flavorings, spices, gums were identified in the study area. An expansive number of species belonged to food were Poaceae (8 species), Rutaceae (7 species), Fabaceae (6 species), Moraceae and Rosaceae ( 5 species each), Brassicaceae, Lamiaceae and Solanaceae (4 species each), Alliaceae, Apiaceae, Asteraceae, Musaceae, Myrtaceae (3 species each), Anacardiaceae and Cupressaceae 2 species each, and other 23 families have single species representation. Of these food crops, fruit plants were represented by 38 (45\%) species. A large number of fruits belonged to Rutaceae (6 species), Rosaceae and Moraceae had 5 species each. The fruit plant species kok (Prunus persica) and duba (Cucurbita pepo) were found in all kebeles. Foremost commonly utilized flavors were Rhamnus prinoides and the common vegetable crop that occurred in all sampled kebeles was Brassica carinata. The majority of food crops were herbs $35(41 \%)$ followed by shrubs $26(30.6 \%)$, trees $18(21 \%)$ and climbers $6(7 \%)$.

\section{Medicinal plants}

A total of 83 plant species with medicinal values were recorded and this accounted for $35 \%$ of the total plant species documented. Species of the families Asteraceae, Rosaceae, Fabaceae, Rutaceae, Lamiaceae, Cucurbitaceae, Solanaceae, Poaceae were the most used for traditional remedy preparation representing $38.6 \%$ of all medicinal plants. The majority of medicinal plants were shrubs 31 (37. \%) followed by herbs 21(25.3\%), trees 23(27.7\%) and climbers 8(9.6\%). Justicia shimperiana, Ruta chalepensis, Zehneria scabra, Eucalyptus globulus, and Vernonia amygdalina were common medicinal plants in all study kebeles.

\section{Environmental uses}

Page 5/14 
Environmental useful plants were noted for their uses as fence, hedges, shade and ornamental uses. A total 140(59\%) plant species under 66 Families were recorded for various Environmental uses as live fence, hedges, shade plant and ornamental value. Fabaceae contained the largest number of plant species (15 species) for environmental uses followed by Asteraceae 10, Rosaceae 8, Euphorbiaceae 7, Moraceae and Poaceae 6, Myrtaceae 5, Anacardiaceae 4, Celastraceae, Dracaenaceae, Lamiaceae, Oleaceae 3 species each, Apocynaceae, Arecaceae, Capparidaceae, Commelinaceae, Cupressaceae, Loganiaceae, Malvaceae, Rubiaceae, Rutaceae, Sapindaceae, Solanaceae, Tiliaceae, Verbanaceae had 2 species each. The larger number of plant species used for environmental uses were trees $54(38.6 \%)$, followed by shrubs 49(35\%), herbs 30(21.4\%), cimbers7(5\%). 96.4\% environmental useful plants were Perennials and $3.6 \%$ were annuals.

\title{
3.1 Live Fence
}

Live fence species constituted 112 plant species accounting for $47 \%$ of all the plant species documented, and $85.7 \%$ of the environmentally useful plants recorded. Plants recorded as live fence plants in all sampled kebeles were Justicia schimperiana, Eucalyptus globulus and Vernonia amygdalina.

\subsection{Omamental plants}

Ornamental plants species covered $21 \%$ (50 species) of the total plant species recorded and $35.7 \%$ of the environmentally useful plants. Cupressus lusitanica was commonly reported among all the sample kebeles followed by Rosa richardii and Dahlia pinnata. Most of the ornamental plants were recorded from the Wenka kebele.

\begin{abstract}
4.Materials
Plants categorized in this group were those species reported for their uses for construction materials, agricultural tools, roof thatch, diverse culturally useful instrument and making ropes. A total of 57 plant species (24\%) were documented. The commonly reported plants cited were Eucalyptus globulus, Eucalyptus camaldulensis and Eucalyptus saligna.
\end{abstract}

\section{Social use}

The social use plants were the ones reported for their ritual and religious uses, stimulant drugs, smoking's, cosmetics and baking agents. A total of 49 (20.6\%) plant species under 25 families were identified for their social uses. The highest number of social useful plants were found in family Poaceae (7 species) followed by Cyperaceae (6 species) and Asteraceae and Lamiaceae have 5 . The growth form analysis of social use plants indicated dominance of herbs $25(50 \%)$ followed by shrub $13(26 \%)$, trees $11(22 \%)$ and climber $1(2 \%)$.

\subsection{Fragrant and stimulant plants}

Individuals utilize fragrant plants for changing the scent of the encompassing or fabric that can be utilized as a family utensil or they can be utilized as an input of commercially made fragrances. 15(6.3\%) fragrant plant species were identified in the study kebele. And from fragrant plants, Ruta chalepensis and Olea europaea subsp. cuspidata were common in all kebeles. 3(1.26\%) stimulant plant species were recorded in the study area, Coffea arabica was reported at all study kebeles and Catha edulis was found widely dispersed.

\subsection{Plants used for cooking}

Ensete ventricosum and Galium aparinoides were found to be two $(0.84 \%)$ plants utilized for bread and potato preparation.

\section{Fodder}

A total of 39(16.3\%) plant species belonging to 19 families were found identified for their purposes as feed for cattle, sheep, and donkey. Poaceae, with 11 plant species, had recorded, followed by Fabaceae and Cyperaceae, with 5 and 4 plant species, respectively. Snowdenia polystachya was the most prevalent fodder plant, followed by Cenchrus ciliaris, Cynodon dactylon, Zea mays, Vernonia amygdalina, Vernonia myriantha and Malva verticillata.

\section{Fuel}

In the study area, there were 60 fuel plant species belonging to 30 botanical families, accounting for $25 \%$ of the total. The bulk of plant species used for fuel were from the familie Fabaceae. Moraceae and Myrtaceae accounted for $16.7 \%$ of fuel plant species, whereas Anacardiaceae, Asteraceae, Poaceae, and Rosaceae accounted for $20 \%$ of the fuel plant species in the study area.

\section{Poison}

Only $1(0.42 \%)$ plant species was recorded under this category. 
Direct matrix ranking

Direct matrix ranking results indicated that Cordia africana ranked as the most widely harvested plant for its multipurpose uses followed by Ficus sur (table2).

Table 2. Direct matrix ranking result of fifteen multipurpose plants

\begin{tabular}{|c|c|c|c|c|c|c|c|c|c|}
\hline \multirow[b]{2}{*}{ Species } & \multicolumn{9}{|c|}{ Use diversity } \\
\hline & food & Fodder & $\begin{array}{l}\text { Environmental } \\
\text { uses }\end{array}$ & medicine & Materials & fuel & $\begin{array}{l}\text { Social } \\
\text { uses }\end{array}$ & total & rank \\
\hline Vernonia amygdalina Del. & 0 & 5 & 5 & 5 & 2 & 4 & 5 & 26 & 3 \\
\hline Cordia africana Lam. & 4 & 4 & 4 & 4 & 5 & 5 & 4 & 30 & 1 \\
\hline Cupressus Iusitanica Mill. & 3 & 3 & 4 & 0 & 5 & 4 & 0 & 19 & 11 \\
\hline Dracaena steudneri Engl. & 0 & 4 & 3 & 5 & 0 & 0 & 5 & 17 & 14 \\
\hline Ficus surForssk. & 5 & 4 & 5 & 4 & 3 & 4 & 3 & 28 & 2 \\
\hline Ficus vasta Forssk. & 4 & 4 & 5 & 0 & 4 & 4 & 4 & 25 & 4 \\
\hline Acacia abyssinica Hochst. ex. & 3 & 4 & 4 & 4 & 4 & 4 & 0 & 23 & 6 \\
\hline Albizia schimperiana Oliv. & 0 & 4 & 3 & 4 & 5 & 4 & 4 & 24 & 4 \\
\hline Myrica salicifolia Hochst. ex A. Rich. & 3 & 4 & 3 & 4 & 4 & 4 & 0 & 22 & 7 \\
\hline $\begin{array}{l}\text { Syzygium guineense (Willd.) DC. subsp. } \\
\text { Guineense }\end{array}$ & 5 & 4 & 3 & 0 & 4 & 4 & 0 & 20 & 8 \\
\hline $\begin{array}{l}\text { Olea europaea L. subsp.cuspidata (Wall. } \\
\text { ex G.Don)Cif. }\end{array}$ & 0 & 0 & 3 & 5 & 5 & 0 & 5 & 18 & 12 \\
\hline Prunus africana (Hook.f.)Kalkm. & 0 & 0 & 3 & 0 & 5 & 5 & 5 & 18 & 12 \\
\hline Salix subserrata Willd. & 0 & 4 & 3 & 0 & 4 & 4 & 5 & 20 & 8 \\
\hline Grewia ferruginea Hochst. exA. Rich. & 4 & 5 & 3 & 4 & 0 & 4 & 0 & 20 & 8 \\
\hline Celtis africana Burm. $\mathrm{f}$. & 0 & 4 & 2 & 0 & 4 & 4 & 0 & 14 & 15 \\
\hline Total & 31 & 53 & 53 & 39 & 54 & 54 & 40 & & \\
\hline Rank & 7 & 3 & 3 & 5 & 1 & 1 & 5 & & \\
\hline
\end{tabular}

User criteria 5 = best, 4 = very good, $3=$ good, 2 = less used, $1=$ least used, $0=$ not used

\section{Use value}

Table3. The result of 12 informants interviewed about the multiple use of Cordia africana 


\begin{tabular}{|c|c|c|c|c|c|c|c|c|}
\hline Informants & Food & Fodder & $\begin{array}{l}\text { Environmental } \\
\text { uses }\end{array}$ & Fuel & Medicine & Material & Social use & Total Ui \\
\hline A & 5 & 3 & 3 & 4 & 4 & 5 & 5 & 4.1Uv1 \\
\hline B & 4 & 4 & 4 & 3 & 3 & 5 & 4 & $3.8 \mathrm{Uv} 2$ \\
\hline C & 4 & 5 & 3 & 4 & 4 & 5 & 5 & 4.3 Uv3 \\
\hline D & 5 & 4 & 3 & 4 & 3 & 5 & 4 & 4 Uv4 \\
\hline E & 3 & 3 & 4 & 3 & 3 & 5 & 4 & 3.7 Uv5 \\
\hline $\mathrm{F}$ & 5 & 4 & 4 & 5 & 4 & 5 & 5 & 4.6 Uv6 \\
\hline G & 4 & 5 & 5 & 3 & 4 & 5 & 4 & 4.4 Uv7 \\
\hline $\mathrm{H}$ & 3 & 4 & 5 & 4 & 4 & 5 & 4 & 4 Uv8 \\
\hline I & 3 & 5 & 4 & 3 & 3 & 5 & 5 & 4 Uv9 \\
\hline $\mathrm{J}$ & 5 & 5 & 3 & 4 & 5 & 5 & 4 & 4.6 Uv10 \\
\hline K & 3 & 3 & 4 & 4 & 4 & 5 & 5 & 4 Uv11 \\
\hline L & 4 & 3 & 4 & 4 & 3 & 5 & 4 & 4 Uv12 \\
\hline Total & 48 & 48 & 46 & 45 & 44 & 60 & 53 & $49.5 \sum \mathrm{Ui}$ \\
\hline Mean & $\begin{array}{l}4 \mathrm{Uv} \\
\text { food }\end{array}$ & $\begin{array}{l}4 \mathrm{Uv} \\
\text { fodder }\end{array}$ & 3.83 Uv Eu & $\begin{array}{l}3.75 \mathrm{Uv} \\
\text { fuel }\end{array}$ & 3.67 Uv medicine & 5Uv Material & $4.42 \mathrm{Uv} \mathrm{Su}$ & $4.1 \mathrm{Uv}$ \\
\hline
\end{tabular}

The total use value of Cordia africana total use value was 4.1, and its largest use value was recorded for its material use.

\section{Similarity among Homegardens}

For all the plants collected across the 357 homegardens, Sorenson's Index was calculated. Table 4 shows the Species composition similarity index value across homegardens in the twelve kebeles.

Table 4. Level of Similarity index among kebeles in composition of plant species

\begin{tabular}{|c|c|c|c|c|c|c|c|c|c|c|c|c|}
\hline $\begin{array}{l}\text { Study } \\
\text { kebeles }\end{array}$ & Wenka & $\begin{array}{l}\text { Addis } \\
\text { enagulit }\end{array}$ & Yeboargina & Kebi & $\begin{array}{l}\text { Desa } \\
\text { Enese }\end{array}$ & $\begin{array}{l}\text { Aba } \\
\text { Libanos }\end{array}$ & Denba & Chimt & Enerata & Graram & Yebokla & Yetgan \\
\hline Wenka & 1 & & & & & & & & & & & \\
\hline $\begin{array}{l}\text { Addisena } \\
\text { gulit }\end{array}$ & 0.46 & 1 & & & & & & & & & & \\
\hline Yeboargina & 0.44 & 0.52 & 1 & & & & & & & & & \\
\hline Kebi & 0.41 & 0.51 & 0.6 & 1 & & & & & & & & \\
\hline $\begin{array}{l}\text { Desa } \\
\text { Enese }\end{array}$ & 0.35 & 0.48 & 0.51 & 0.45 & 1 & & & & & & & \\
\hline $\begin{array}{l}\text { Aba } \\
\text { Libanos }\end{array}$ & 0.42 & 0.43 & 0.42 & 0.39 & 0.43 & 1 & & & & & & \\
\hline Denba & 0.38 & 0.45 & 0.51 & 0.49 & 0.53 & 0.55 & 1 & & & & & \\
\hline Chimt & 0.26 & 0.38 & 0.4 & 0.4 & 0.46 & 0.33 & 0.48 & 1 & & & & \\
\hline Enerata & 0.45 & 0.58 & 0.5 & 0.5 & 0.46 & 0.43 & 0.42 & 0.35 & 1 & & & \\
\hline Graram & 0.28 & 0.35 & 0.37 & 0.41 & 0.29 & 0.32 & 0.3 & 0.25 & 0.42 & 1 & & \\
\hline Yebokela & 0.36 & 0.46 & 0.45 & 0.43 & 0.38 & 0.35 & 0.37 & 0.33 & 0.44 & 0.39 & 1 & \\
\hline yetgan & 0.43 & 0.58 & 0.6 & 0.52 & 0.5 & 0.46 & 0.51 & 0.39 & 0.52 & 0.37 & 0.43 & 1 \\
\hline
\end{tabular}


The highest similarity index was found between Yboargena and Kbi, Yboargena and Ytegan, indicating that they shared $60 \%$ of the plant species. Chimt and Graram, on the other hand, had the lowest similarity values, meaning they shared only $25 \%$ of the plant species. The similarity index is larger than 0.5 in $36 \%$ of the cases, and less than 0.5 in $64 \%$ of the cases.

\section{Discussion}

Homegardens are crucial in the conservation of beneficial plant species, since they contain numerous species which are often absent or disappearing from other production systems [34]. In accordance with this, the current study indicated that a high number of plant species (238) were recorded from in the homegardens of Gozamin District. This agrees with the high tree species richness reported for Gozamin compared to similar highland agroecosystems such as that of the Jabithenan district in Northwestern Ethiopia, where 69 species from 40 families were reported [23], the Bulen district in Northwestern Ethiopia, where 22 plant species from 15 families were recorded [35], and Southern Tigray, Northern Ethiopia, where 32 plant species from 20 families were recorded[13].

The size of overall homegarden used for plantation in the study area ranged from 0.015 ha to 0.5 ha which shows some variations with other homegardens reported from the same agroecology Jabithenan district reported 0.05 to 0.5 ha size [23] and 0.004 to 0.05 ha in Ethiopia [22].

Environmental variables and dietary preferences, as well as socioeconomic and commercial needs, are all reported for their influence in the distribution of species in homegardens[36]. The number of plant species varied between sites as observed in the current study area. Since there was irrigation water and Wenka is close to the main town Deberemarkos, it had a significant number of homegarden species, (130 species in 58 families). The site supplied food crops to Debremarkos town, primarily fruits and vegetables, and this encouraged farmers to sell their homegrown produce in areas with strong market access $[11,37]$.

In the study area, homegardening provides subsistence food production and family food security by producing vegetables, fruits, cereals, spices, beverages. Such wide use and service of homegardens was also reported by other authors [38-43]. Fruits were the most commonly utilized plant parts from food crops in the studied homegardens. The result goes in line with other reports [40, 42, 44]. This shows homegardens are the main sources of fruits.

A total of 83 therapeutic plants were found in selected homegardens. This demonstrates that gardening has placed a greater emphasis on human health and well-being[1]. Dracaena steudneri was found with medicinal properties for treating livestock ailments, it was also cited for treating bad sprits, besides its decorative nature, fodder, shade plant, fence and other cultural and hence was common within the study area. This proves that cultural value has center point for preserving plants this also founded by [45].

Environmental useful plants as fence, shade and ornamental plants cover $140(58.6 \%)$ plant species under 66 Families. This was supported by Kumar and Nair [17] who showed homegardens were praised for preserving biodiversity and preventing environmental degradation.

Fence plants were the most common species in home gardens, where they serve as a barrier to keep fruits, vegetables, spices, and other items safe. This culture on the study site keeps diverse plant species safe around their homes and gardens. The study found that the majority of the homegardens analyzed were encircled by a live fence this was in agreement with other works in Ethiopia [12, 35].

Social useful plants account $50(21 \%)$ of the species identified and use for religious ceremonies, stimulants, smoking and baking purpose. Coffea arabica, which was used in households and for the market, was discovered in all study sites, and Catha edulis, which was utilized for the market to generate income, was also detected in most study sites. This was also shown in other research findings [11, 35]. Also, Mellisse et al. [46] recently reported that, there has been a dramatic movement away from conventional family gardens toward cash crop Catha edulis based systems, especially in locations near marketplaces. A total of $2(0.84 \%)$ plants were found to be utilized in the preparation of bread and potatoes. Ensete ventricosum which was used for baking bread, potting injera, and malting malt, was described as having a nutraceutical nature only [41, 47-49], Galium aparinoides was a weed that was commonly used to cook potatoes since it cooks it quickly and had a wonderful flavor, however Mekonen et al. [41] classified it as a weed that affects the variety and productivity of homegarden plants.

Snowdenia polystachya, which grows readily when there was enough water, was the highest fodder plant recorded, followed by Cenchrus ciliaris and Cynodon dactylon, which grow in front of the respondents' house to feed their cattle, sheep, and donkey. Because it was cited as a multipurpose plant in the area as a food plant, fodder, and fuel; the stem of Zea mays was used as fodder and fuel in the area. Vernonia amygdalina and Vernonia myriantha were more common in the garden because of their multifunctional uses for fodder, medicinal, fence, fuel, and other cultural values, likewise the root wax of Malva verticillata, is used as fodder for small calves in the region. This is in line with Nair [50], who states that multifunctional tree species were the foundation of most tropical backyard gardens.

In the area, 60 (25\%) fuel plant species in 30 families were discovered, indicating that local residents cover some of the fuel demand from gardens. Similar fuel demand was reported by Xiaohua et al.[51]. Also evident in Sub-Saharan Africa that about $76 \%$ of the population (93\% of the rural and $58 \%$ of the urban) cooks with biomass fuel. 
The similarity index for $64 \%$ of the locations investigated was less than 0.5 , suggesting that there was less similarity/high species diversity in the area. This might be due to differences in agroecological conditions amongst sites, as evidenced by Ertiro et al. [52], which demonstrates that agroecology has an impact on variation.

The direct matrix index revealed that Cordia africana, a multifunctional culturally important plant in the area was also extremely endangered, came first, followed by Ficus sur and Vernonia amygdalina. Cordia africana had the highest use-value for construction and the lowest usevalue for medicinal. These findings suggested that these culturally significant multifunctional species were presently being used increasingly to make material and other cultural uses. Cupressus lusitanica was a common plant in all sampled kebeles because of its multipurpose function as an ornamental plant, for construction and building; as gum used in food, forage, fence fuel, and this was also reported by Mekonen et al. [41]. From fragrant plants, Ruta chalepensis and Olea europaea subsp.cuspidata were common in all kebeles this was also supported by Lulekal et al.[53]. Olea europaea subsp. Cuspidata was also noted for its multipurpose value as medicine, cultural value, building, fragrance, fence. People in the study area believed that the fumigation of Olea europaea subsp. Cuspidata in the house by leaves and stems remove bad spirits and bad odors from the house, also used to fumigate milk, Tela and Tej (local beverages) pots this agrees with [54].

Herbs were the most common species in the homegardens in the current study. Mekonen et al.[41] and Regassa [40] agreed with this, whereas Mengestu [42] claimed that trees were the dominating species in the Dilla Zuriya district. The Poaceae, Fabaceae, and Asteraceae families had the most species in the study area, this might be owing to the dominance of the Fabaceae, Asteraceae, and poaceae families in Ethiopian and Eritrean flora, as mentioned in [55-57].

Year-round, a variety of items such as vegetables, fruits, and spices, as well as building and construction materials, medicinal plants, plant species used for fire, and culturally important plants, are grown and sold at the local market. This allowed farmers to be encouraged by selling homegrown items in their region with easy access to markets[11,37].

\section{Conclusion}

Homegardening gives subsistence food production and family food security by producing vegetables, fruits, cereals, spices, beverages. In other words, homegardens are seen as a multi-functional, long-term generating systems.

Plant species that are culturally important have a high value in terms of family household income production, food security, therapeutic, decorative, and other nonfood ways of life though cultural value may be a key figure in biodiversity preservation. Food security and biodiversity preservation are continuously supported by tribal populations' cultural knowledge connected with their homegardens.

Because there were numerous homegarden plant species within the study area and the area had less forest cover, legitimate homegarden management is the foremost vital way to preserve biodiversity, and contribute to ecosystem services in the consider area.

\section{Declarations}

\section{Ethics approval and consent to participate}

District officers and traditional leaders of local communities were visited at each study location to gain their permission to conduct interviews in the area under their control. Participants were told orally of the research aims and their right to participate or withdraw prior to conducting interviews. After the interview, participants signed a written format expressing that they agreed that the interview followed the principle of prior informed consent.

\section{Consent for publication}

Not applicable

\section{Competing interests}

The authors declare that they have no competing interests

\section{Acknowledgements}

I am grateful to thanks informants involved to provide their knowledge, Gozamin district Agricultural and Health officers, Kebele Agricultural and health experts, and field guiders who were devoted guide me to the local communities in the study areas. Finally, I would like to thank you Addis Ababa University for Financial support to carry out our research.

\section{Authors 'contributions}


Metsehet Yinebeb is the main author, involved in the methodology, fieldwork, and data analysis, wrote the first draft and concluded the final version of this paper. Dr Ermias Lulekal and Prof. Tamrat Bekele are the main supervisors of the research work, participated in the design and monitoring of the research and data analyses and reviewed several drafts of the manuscript. All authors read and approved the final manuscript.

\section{Funding}

All the financial cost and required research logistics of the research was fully funded by Addis Ababa university.

\section{Availability of data and materials}

All data analyzed during this study are included in this published article.

\section{References}

1. Chalmin-Pui, L.S., et al., Why garden? - Attitudes and the perceived health benefits of home gardening. Cities, 2021. 112: p. 103118.

2. Kumar, B.M. and P. Nair, Tropical homegardens. 2006: Springer.

3. Depenbusch, L., et al., Impact of homegarden interventions in East Africa: Results of three randomized controlled trials. Food Policy, 2021. 104: p. 102140.

4. Milow, P., et al., Diversity of plants tended or cultivated in Orang Asli homegardens in Negeri Sembilan, Peninsular Malaysia. Human Ecology, 2013. 41(2): p. 325-331.

5. Buchmann, C., Cuban homegardens and their role in social-ecological resilience. Human Ecology, 2009. 37(6): p. 705-721.

6. Senanayake, R., et al., Vegetation composition and ecological benefits of homegardens in the Meegahakiula region of Sri Lanka. 2009.

7. Das, T. and A.K. Das, Inventorying plant biodiversity in homegardens: A case study in Barak Valley, Assam, North East India. Current science, 2005: p. 155-163.

8. Abdoellah, O.S., et al., Commercialization of homegardens in an Indonesian village: vegetation composition and functional changes, in Tropical Homegardens. 2006, Springer. p. 233-250.

9. Kehlenbeck, K. and B. Maass, Are tropical homegardens sustainable? Some evidence from Central Sulawesi, Indonesia, in Tropical Homegardens. 2006, Springer. p. 339-354.

10. Méndez, V.E., R. Lok, and E. Somarriba, Interdisciplinary analysis of homegardens in Nicaragua: micro-zonation, plant use and socioeconomic importance. Agroforestry systems, 2001. 51(2): p. 85-96.

11. Hirvonen, K. and D. Headey, Can governments promote homestead gardening at scale? Evidence from Ethiopia. Global food security, 2018 19: p. 40-47.

12. Asfaw, Z., Homegardens in Ethiopia: some observations and generalizations. Homegardens and in situ conservation of plant genetic resources in farming systems, 2002: p. 125.

13. Eyasu, G., M. Tolera, and M. Negash, Woody species composition, structure, and diversity of homegarden agroforestry systems in southern Tigray, Northern Ethiopia. Heliyon, 2020. 6(12): p. e05500.

14. Jarvis, D.I., L. Myer, and H. Klemick, A training guide for in situ conservation on-farm. 2000: Bioversity International.

15. Galluzzi, G., P. Eyzaguirre, and V. Negri, Homegardens: neglected hotspots of agro-biodiversity and cultural diversity. Biodiversity and conservation, 2010. 19(13): p. 3635-3654.

16. Gautam, R., et al., Homegardens management of key species in Nepal: a way to maximize the use of useful diversity for the well-being of poor farmers. Plant Genetic Resources, 2009. 7(2): p. 142-153.

17. Kumar, B.M. and P.R. Nair, The enigma of tropical homegardens. Agroforestry systems, 2004. 61(1-3): p. 135-152.

18. Mohan, S., An assessment of the ecological and socioeconomic benefits provided by homegardens: A case study of Kerala, India. 2004: University of Florida.

19. High, C. and C.M. Shackleton, The comparative value of wild and domestic plants in homegardens of a South African rural village. Agroforestry systems, 2000. 48(2): p. 141-156.

20. Landon-Lane, C., Livelihoods grow in gardens. Rome, Italy: Food and Agriculture Organization of the United Nations. 2011.

21. Lamont, S.R., W.H. Eshbaugh, and A.M. Greenberg, Species composition, diversity, and use of homegardens among three Amazonian villages. Economic Botany, 1999. 53(3): p. 312-326. 
22. Zemede, A. and N. Ayele, Home-gardens in Ethiopia: characteristics and plant diversity. SINET, an Ethiopian Journal of Science, 1995. 18(2): p. 235-266.

23. Asfaw, Z., E. Linger, and S. Zewudie, Plant Species Richness and Structure of Homegarden Agroforestry in Jabithenan District, NorthWestern Ethiopia. International Journal of Environmental Sciences, 2015. 4(2): p. 52-58.

24. GAO, Gozamin agricultural office report. 2021.

25. CSA, Summary and statistical report of the 2007 population and housing census. Population size by age and sex. 2007.

26. GHO, Gozamin health office report. 2021.

27. Cochran, W.G., Sampling techniques-3. 1977.

28. GKA, Gozamin district kebeles agricultural office 2021.

29. Dissanayake, D. and P. Hettiarachchi, Floristic Composition of Home-garden Systems in Dumbara (Knuckles) Conservation Area with an emphasis on Endemic Species. Journal of Tropical Forestry and Environment, 2013. 3(1).

30. Millate-E-Mustafa, M., J.B. Hall, and Z. Teklehaimanot, Structure and floristics of Bangladesh homegardens. Agroforestry systems, 1996. 33(3): p. 263-280.

31. Martin, G., Ethnobotany: a methods manual. Chapman and Hall, London, UK. 1995.

32. Mueller-Dombois, D. and H. Ellenberg, Aims and methods of vegetation ecology. 1974: Wiley.

33. Cook, F.E., Economic botany data collection standard. 1995: Royal Botanic Gardens (Kew).

34. Hodgkin, T. Homegardens and the maintenance of genetic diversity. in Homegardens and in situ conservation of plant genetic resources in farming systems. Proceedings of the Second International HomeGardens Workshop, Witzenhausen, Federal Republic of Germany, 17-19 July, 2001. 2002. International Plant Genetic Resources Institute (IPGRI).

35. Beyene, M., M. Mohammed, and L. Nigatu, Plant Species Diversity and structure in homegarden agroforestry systems of Bulen District, North-Western Ethiopia. Agric For Fish, 2018. 7(3): p. 121-132.

36. Fernandes, E.C. and P.R. Nair, An evaluation of the structure and function of tropical homegardens. Agricultural systems, 1986. 21(4): p. 279-310.

37. Abebe, T., Diversity in homegarden agroforestry systems of Southern Ethiopia. 2005.

38. Kumar, B. and P. Nair, Tropical homegardens. 2006: Springer.

39. Abebe, T., et al., Diversity, composition and density of trees and shrubs in agroforestry homegardens in Southern Ethiopia. Agroforestry systems, 2013. 87(6): p. 1283-1293.

40. Regassa, R., Useful plant species diversity in homegardens and its contribution to household food security in Hawassa city, Ethiopia. African Journal of Plant Science, 2016. 10(10): p. 211-233.

41. Mekonen, T., M. Giday, and E. Kelbessa, Ethnobotanical study of homegarden plants in Sebeta-Awas District of the Oromia Region of Ethiopia to assess use, species diversity and management practices. J Ethnobiol Ethnomed, 2015. 11: p. 64.

42. Mengitu, M. and D. Fitamo, Plant species diversity and composition of the homegardens in Dilla Zuriya Woreda, Gedeo Zone, SNNPRS, Ethiopia. Plant, 2015. 3(6): p. 80.

43. Gabiso, G. and T. Abebe, The Niche of Tree and Crop in Traditional Homegarden Agro forestry system. Case of Agro-biodiversity Conservation at Farm Level in Boricha and Wondo Genet, Sidama, SNNPRs Ethiopia'. J Biodivers Manage Forestry 6, 2017.4.

44. Abebe, T., K. Wiersum, and F. Bongers, Spatial and temporal variation in crop diversity in agroforestry homegardens of southern Ethiopia. Agroforestry systems, 2010. 78(3): p. 309-322.

45. Das, T. and A.K. Das, Conservation of Plant Diversity in Rural Homegardens with Cultural and Geographical Variation in Three Districts of Barak Valley, Northeast India 1. Economic Botany, 2015. 69(1): p. 57-71.

46. Mellisse, B.T., et al., Are traditional homegardens in southern Ethiopia heading for extinction? Implications for productivity, plant species richness and food security. Agriculture, Ecosystems \& Environment, 2018. 252: p. 1-13.

47. Bosha, A., et al., Nutritional and chemical properties of fermented food of wild and cultivated genotypes of enset (Ensete ventricosum). Food Research International, 2016. 89: p. 806-811.

48. Andeta, A., et al., Fermentation of enset (Ensete ventricosum) in the Gamo highlands of Ethiopia: physicochemical and microbial community dynamics. Food microbiology, 2018. 73: p. 342-350.

49. Birmeta, G., A. Bakeeva, and V. Passoth, Yeasts and bacteria associated with kocho, an Ethiopian fermented food produced from enset (Ensete ventricosum). Antonie Van Leeuwenhoek, 2019. 112(4): p. 651-659.

50. Nair, P.R., Agroecosystem management in the 21st century: it is time for a paradigm shift. Journal of Tropical Agriculture, $2008.46:$ p. 1-12.

51. Xiaohua, W., D. Xiaqing, and Z. Yuedong, Domestic energy consumption in rural China: A study on Sheyang County of Jiangsu Province. Biomass and Bioenergy, 2002. 22(4): p. 251-256.

Page 12/14 
52. Ertiro, B.T., et al., Genetic variation and population structure of maize inbred lines adapted to the mid-altitude sub-humid maize agroecology of Ethiopia using single nucleotide polymorphic (SNP) markers. BMC genomics, 2017. 18(1): p. 1-11.

53. Lulekal, E., et al., An ethnobotanical study of medicinal plants in Mana Angetu District, southeastern Ethiopia. Journal of ethnobiology and Ethnomedicine, 2008. 4(1): p. 1-10.

54. Kebede, B. and T. Soromessa, Allometric equations for aboveground biomass estimation of Olea europaea L. subsp. cuspidata in Mana Angetu Forest. Ecosystem Health and Sustainability, 2018. 4(1): p. 1-12.

55. Edwards, S., S. Nemomissa, and I. Hedberg, Flora of Ethiopia and eritrea. 2003: The National Herbarium, Addis Ababa University.

56. Hedberg, I., S. Edwards, and S. Phillips, Flora of Ethiopia and Eritrea, Vol. 7: poaceae (gramineae). 1995: AAU.

57. Hedberg, I., O. Hedberg, and S. Edwards, Flora of Ethiopia and Eritrea. Vol. 3, Pittosporaceae to Araliaceae. 1989: National Herbarium, Addis Ababa University.

\section{Figures}

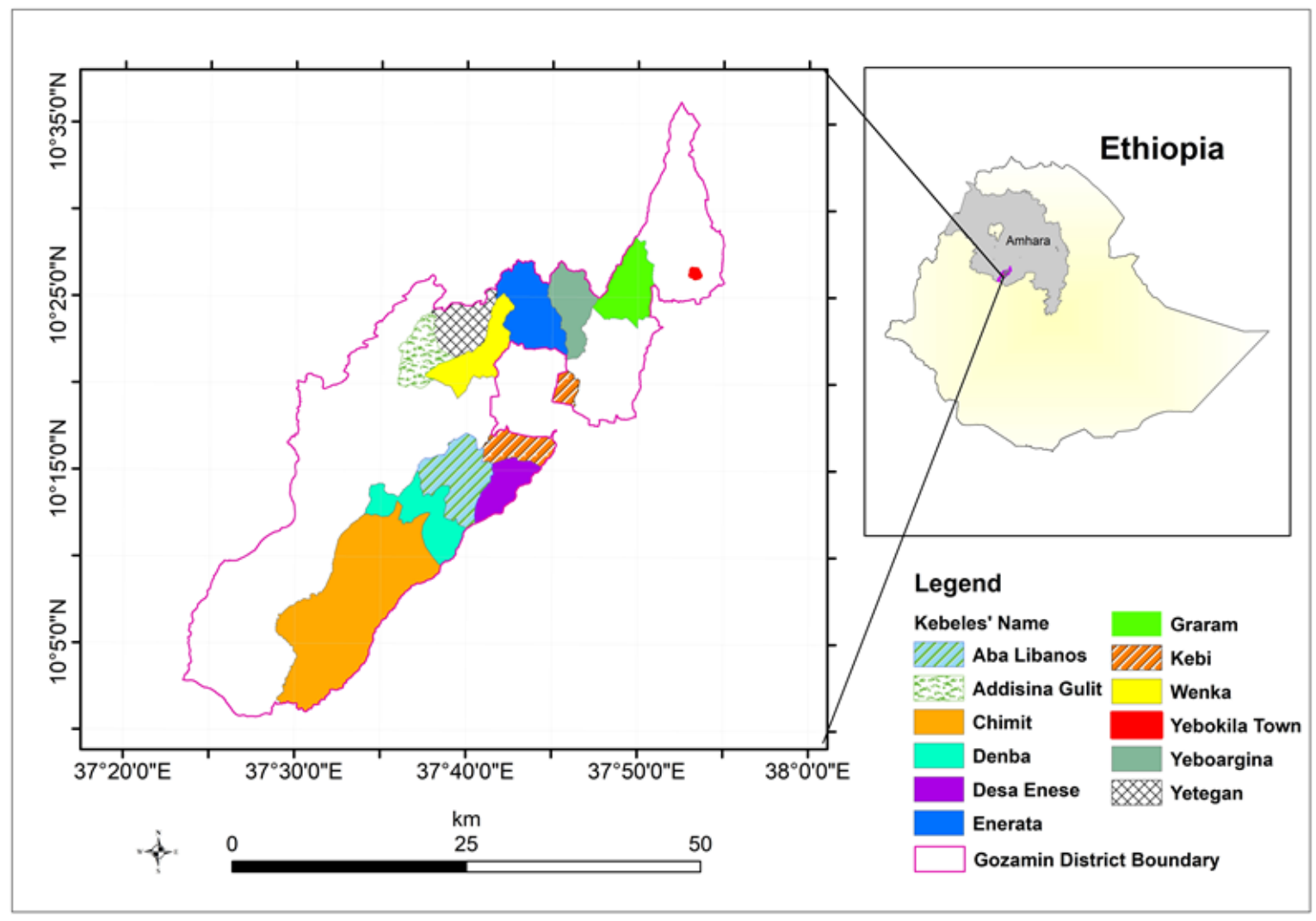

\section{Figure 1}

Map of Ethiopia showing Amhara region and the study district that inhabit an indigenous community 


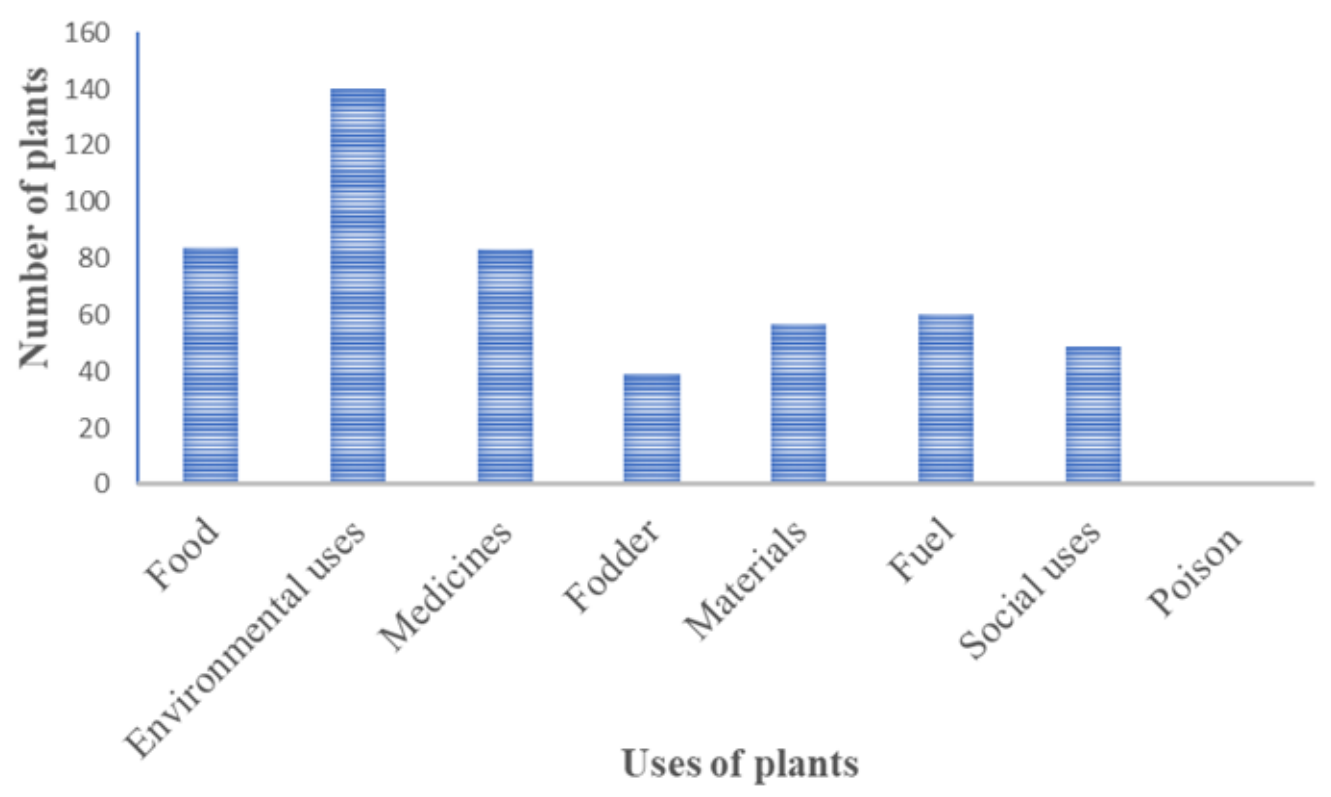

Figure 2

The importance of homegarden plant species in the study areas

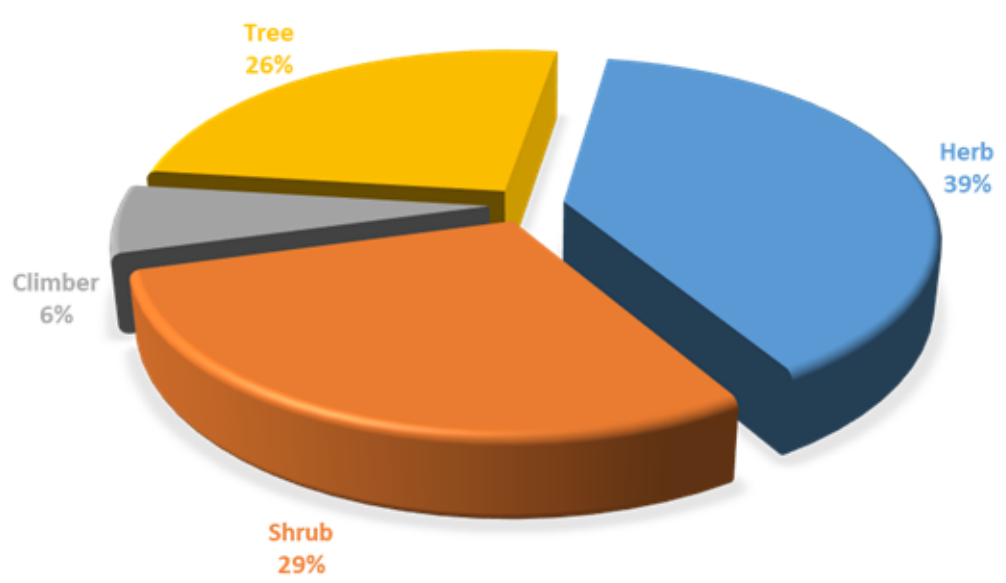

\section{Figure 3}

The habits of important homegarden plant species recorded in the study area 